\title{
Evaluation of serum levels of antioxidant trace elements, zinc, copper, selenium and manganese, in children with acute lymphoblastic leukemia before treatment
}

\author{
Mehrnaz Keshavarzi ${ }^{1}$, Fariba Faraji ${ }^{2}$, Monireh Movahedi ${ }^{3}$ \\ ${ }^{1}$ MSc of Biochemistry, Department of Biochemistry, Faculty of Biology, Tehran North Branch, Islamic Azad University, \\ Tehran, Iran \\ ${ }^{2}$ Assistant Professor, Department of Biochemistry, Faculty of Medicine, Tehran Medical sciences, Islamic Azad \\ University, Tehran, Iran \\ ${ }^{3}$ Professor, Department of Biochemistry, Faculty of biology, Tehran North Branch, Islamic Azad University, Tehran, \\ Iran
}

\begin{abstract}
Background: Reactive oxygen species (ROS) can induce carcinogenesis via DNA injury. Antioxidants participate in cell protection against harmful influence of oxidative stress. The aim of the present study was to assess the levels of antioxidant elements, including $\mathrm{Zn}, \mathrm{Cu}$, Se and $\mathrm{Mn}$, in serum of children with acute lymphoblastic leukemia before treatment.

Materials and methods: In this study, 20 children just diagnosed ALL before chemotherapy (mean age,

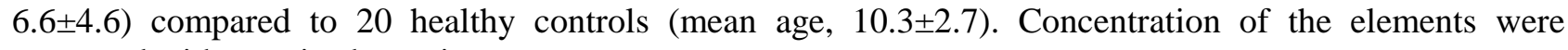
measured with atomic absorption spectroscopy

Results: serum levels of Mn were significantly lower in acute leukemia than in controls $(P=0.03)$, while $\mathrm{Cu}$ was significantly elevated $(P<0.0001)$. There were no significant difference regarding $\mathrm{Zn}$ and Se between two groups ( $P=0.07$ and $P=0.35$, respectively).

Conclusion: Based on obtained results, changes of serum level of these antioxidants could likely have biological role in initiation or progression of leukemia. Further studies are needed to clarify the role of these factors in pathogenesis of acute leukemia

Keywords: Antioxidant trace elements, Acute lymphoblastic leukemia.
\end{abstract}

Cited as: Keshavarzi M, Faraji F, Movahedi M. Evaluation of serum levels of antioxidant trace elements, zinc, copper, selenium and manganese in children with acute lymphoblastic leukemia before treatment. Medical Science Journal of Islamic Azad University, Tehran Medical Branch 2019; 29(1): 48-55.

Correspondence to: Fariba Faraji

Tel: +989124442364

E-mail: faraji_fariba@hotmail.com

ORCID ID: 0000-0003-4383-2491

Received: 15 Jul 2018; Accepted: 16 Sep 2018 
مجله علوم يزشكى دانشگاه آزاد اسلامى

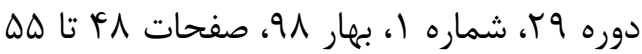

\title{
بررسى سطح سرمى عناصر آنتى اكسيدان روى، مس، سلنيوم و منگَنز در كودكان مبتلا به لوسمى لنفوئيدى حاد قبل از شروع درمان
}

\author{
مهرناز كشاورزى'، فريبا فرجى'، منيره موحدى
}

ا كارشناس ارشد بيوشيمى، كروه بيوشيمى، دانشكده علوم زيستى، واحد تهران شمال، دانشكاه آزاد اسلامى، تهران، ايران

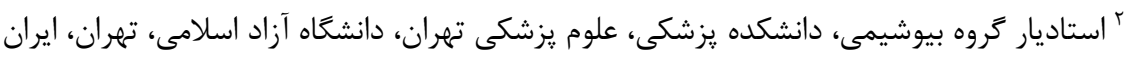

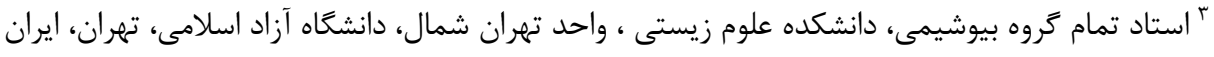

سابقه و هدف: كونههاى فعال اكسيرن ميتوانند/ز طريق استرس اكسيداتيو موجب آسيب زدن به DNA و ايجاد سرطان شوند. عوامل آنتى آنى

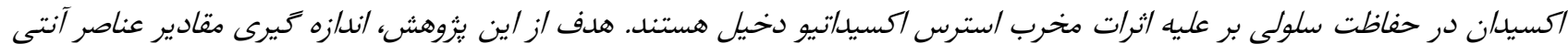

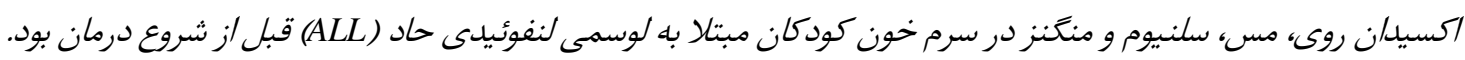

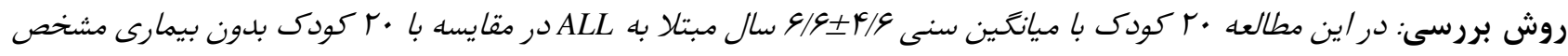

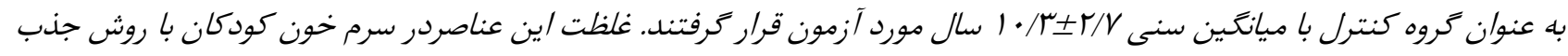
اتمى مورد بررسى قراركرفت.

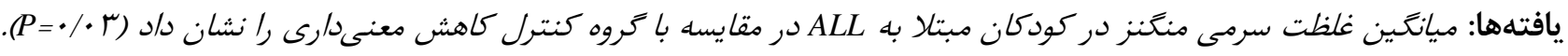

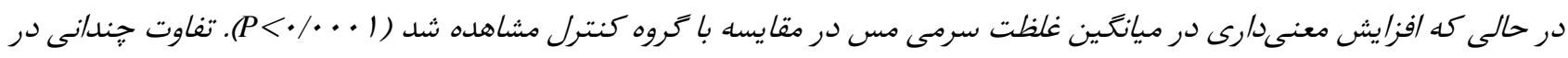

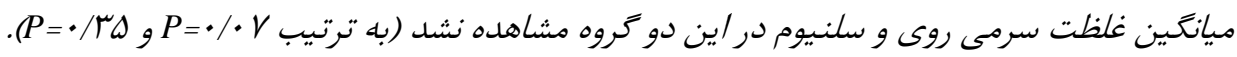

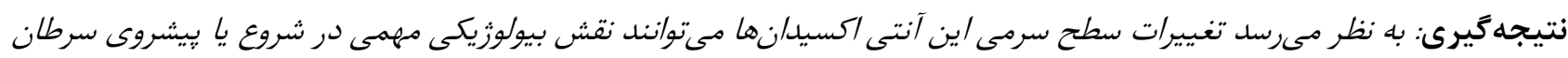

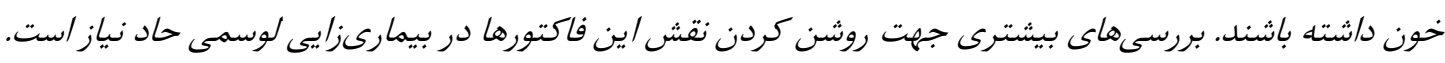

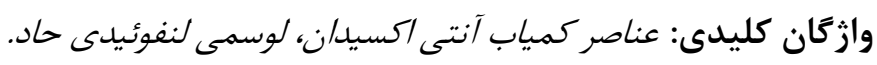

غربالكرى دورهاى نقش كليدى در مديريت مطلوب فراينـدهاى مقدمه

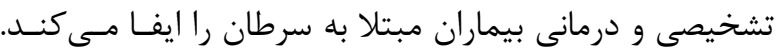

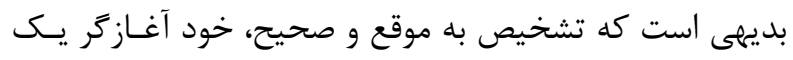

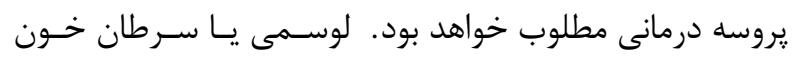

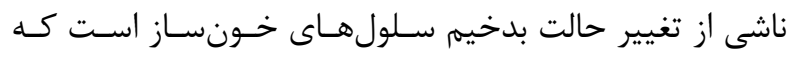

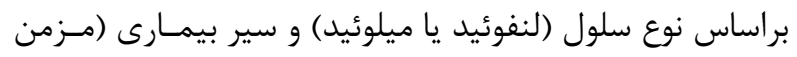

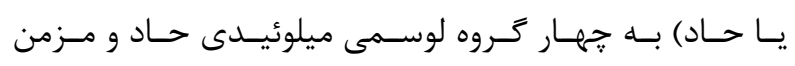
و لوسـمى لنفوئيسـدى حـاد و مــزمن (CML،AML) (CLL

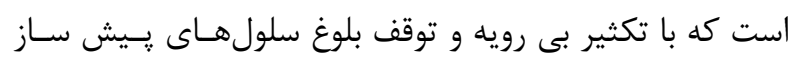
لنفوئيدى در مغز اسـتخوان نمايـان مسىشـود و سـبب ايجـاد

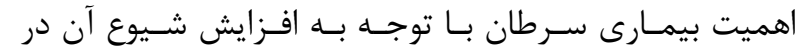

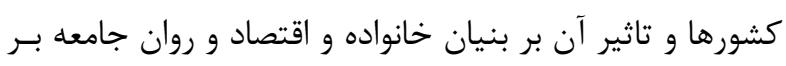

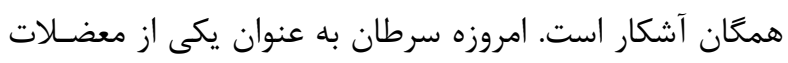

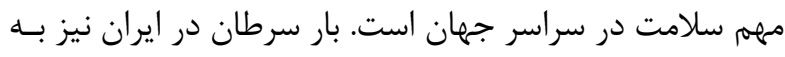

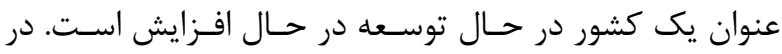

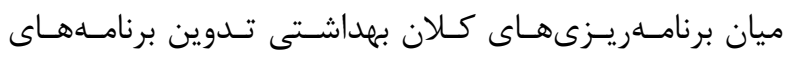

آدرس نويسنده مسئول: تهران، علوم يزشكى تهران، دانشكاه آزاد اسـلامى، تهـران، خـروه بيوشسيمى، دكتـر فريبا فرجى (email: faraji_fariba@hotmail.com) ORCID ID: 0000-0003-4383-2491 تاريخ دريافت مقاله: تV تاريخ بذيرش مقاله: GV/9/TO 
بيولوزيك سلولى دارد. روى هم از عناصـر آنتسى اكسـيدان مهـمه

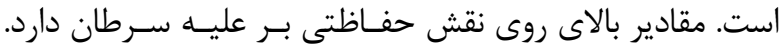

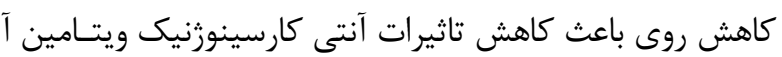

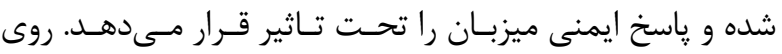

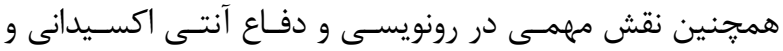

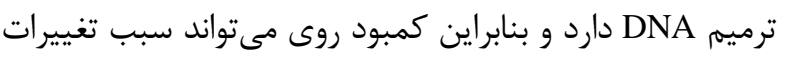

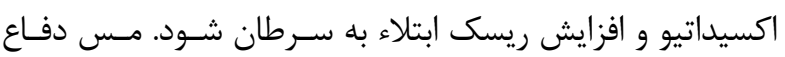

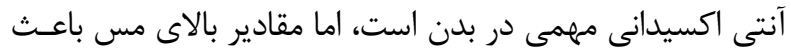

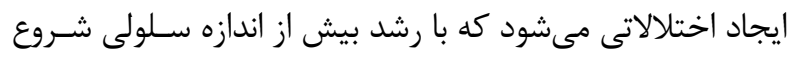

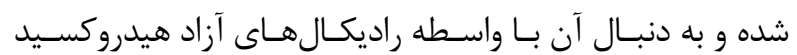

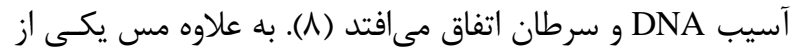

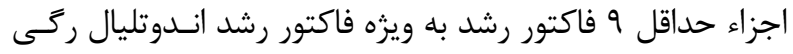

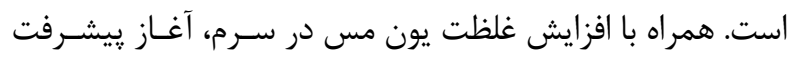

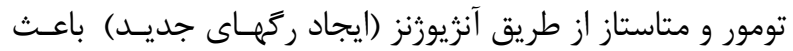
رشد تومور و تثبيت آن مىشود (9).

\section{مواد و روشهها}

خونكَيرى از كودكان بسترى و يـا مراجعـه كنـــــه بـه بيمارسـتان

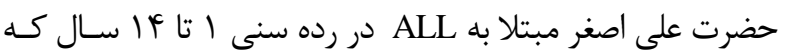

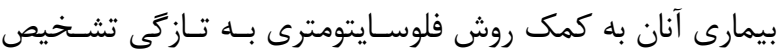

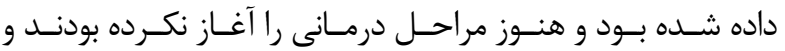

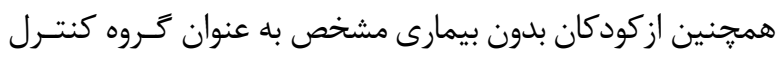
در همان رده سنى انجام كرفت.

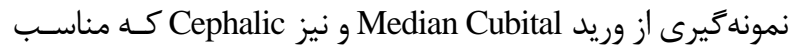

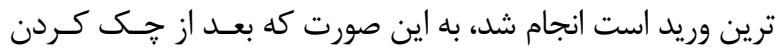

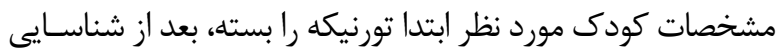

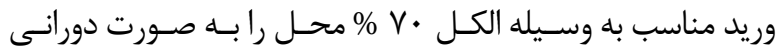

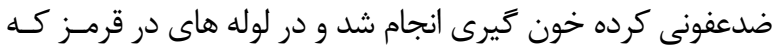

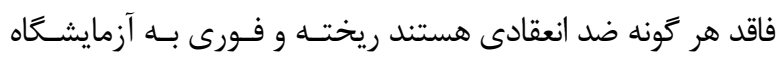

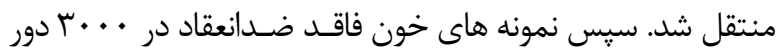
در دقيقه به مدت • ا دقيقه سانتريفوز شدند و جداسازى سرم آنهـا

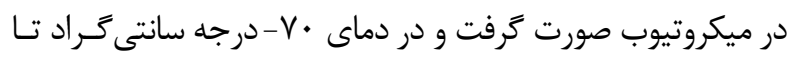
زمان انجام آزمايشات نكهدارى شدند.

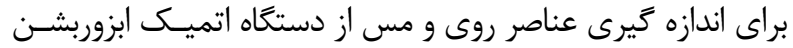

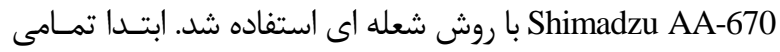

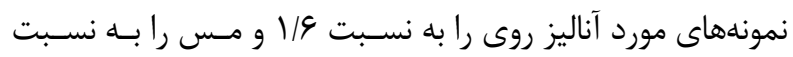

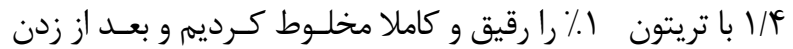
دكمه IGNITE و روشن شدن شعله ابتدا با آب ديونيزه (بلانـك)،

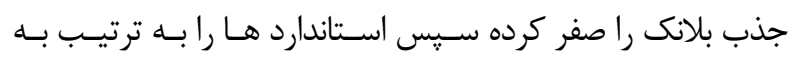

سلولهاى بدخيم مىشـود. در واقـع لنفوبلاسـتهـا جـايكزين

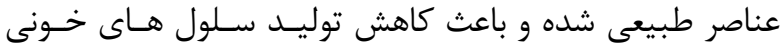
مىشوند. ALL بيمارى است كه در اثر بيان غيرطبيعى زنهـيـا

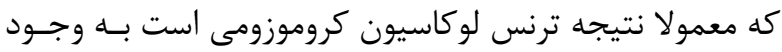

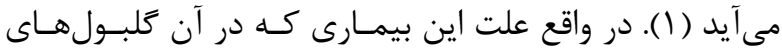

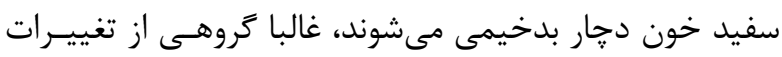

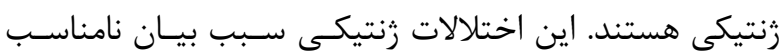
انكوزن ها و از دست دادن عملكرد زنهاى مهار كننده سـرطان

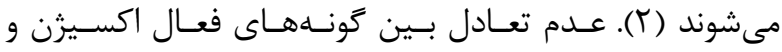

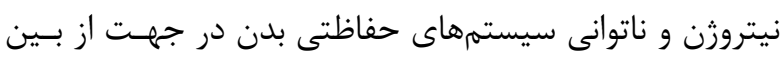
بردن آنها منجر به ايجاد مواد اكسيدان مىشوند. استرسهـاى بـاى غذايى كه با افزايش مصـرف كربوهيـدرات و جربسى در رزيـهم

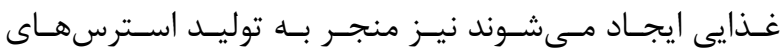
اكسيداتيو مىشوند كه نقش آنها در ايجاد سرطان و بسـيارى از بيمارىهاى ديخر به اثبات رسيده است (باّ). بهترين راهحـل

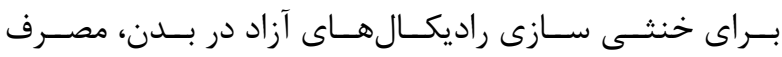

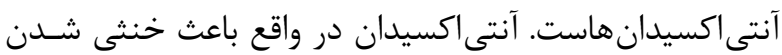

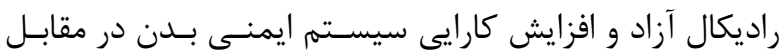

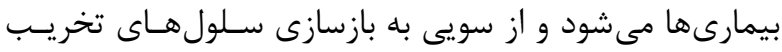

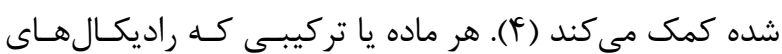

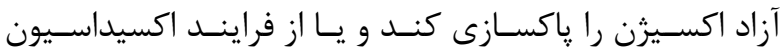

سلولى جلوگيرى كند آنتى اكسيدان ناميده مى شود (ه).

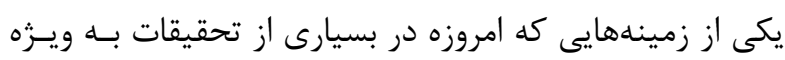
تحقيقات درباره انواع سرطانها مورد توجه قرار كرفتـه اسـته بررسى نقش عناصر كمياب در ايجاد و پيشرفت انـواع سـرطان

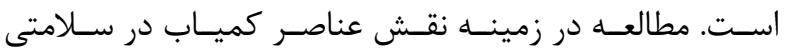
انسانها امروزه به يكى از رشتههاى يررونق بزشكى تبديل شـده

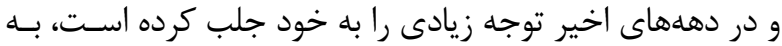

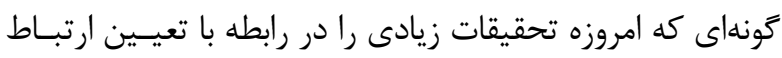

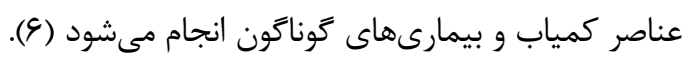

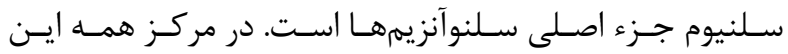
يروتئينها، اسيد آمينه سلنوسيستئين وجود دارد كه بــه عنــوان

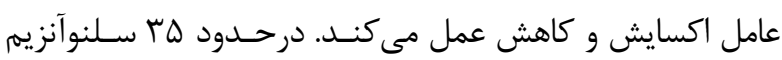

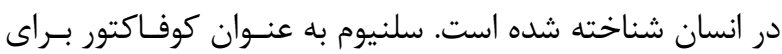
احياء آنزيمهاى حياتى كلوتاتيون يراكسيدازها ضرورى است، كه

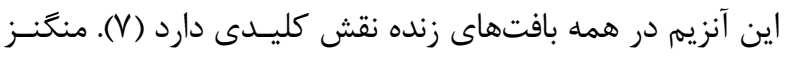

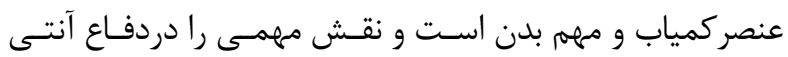

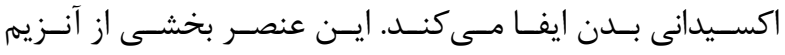

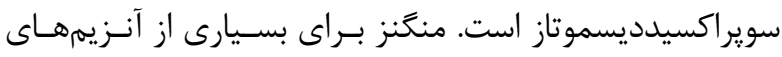

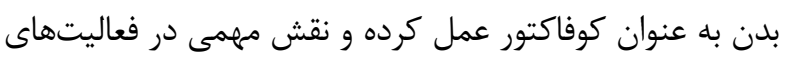




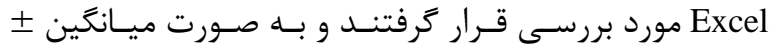
انحراف معيار ارائه شدند. ه • ••>P به عنوان سطح معنى دارى در نظر گرفته شد.

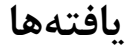

با توجه به جدولهاى ا و Y نتايج سنجش متغيرهاى مختلـف

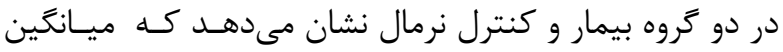
غلظت روى در سرم خون گروه بيماران نسبت به كروه كنتــرل نرمال (a) كـاهش يافت، امـا ايسن كـاهش معنسى دار نبـود. در مقايسه جنسيتى، درگروه يسران بيمار نسبت به گَروه يسـران

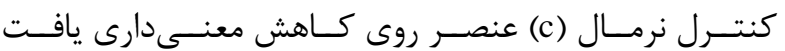

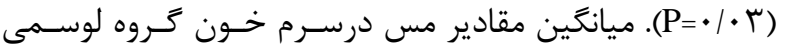
نسبت به گرووه كنترل افزايش معنى دارى داشت. نتايج سنجش

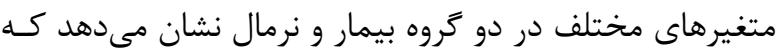

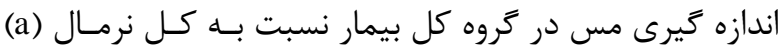

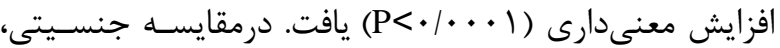

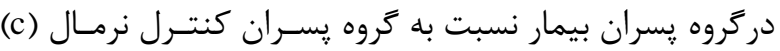

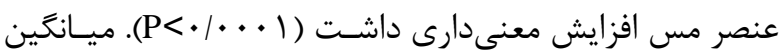
مقادير سلنيوم درسرم خــون گَروه لوســمى نسـبت بــه گَروه
دستَاه داده تا به طور كامل توسط شلنَ مربوطه ساكشن كنـد و منحنى مناسب را رسم كند. بعد از رسم منحنسى در صـورت نيـاز

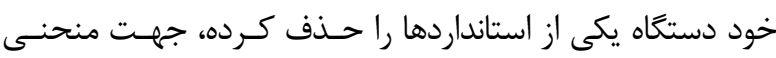
مناسبتر خود غلظتى حدواسط استانداردهاى ما در منحنى رسـم كرد. بعد از رسم منحنى مناسب، تمامى نمونهها بـه دسـتغاه داده شد و جذب هر كدام به جـاب رسـيد. تمـامى نتـايج دسـتَّاه بـر اساس mg/L است كه با انجام محاسبه زير هـم رقت مـورد نظـر اعمال شده و هم بر حسب g/dL نتايج حاصل شد. $=\times 1 \cdots / 1 \cdot \times(\boldsymbol{g} / \mathbb{4})$

Shimadzu AA- براى اندازه گيـرى سـلنيوم و منگَنـز از دسـتـاه 670G با روش كوره استفاده شد. تمامى نمونههاى مـورد آنـاليز را به نسبت ك/1 با تريتـون ا / رقيـق و مخلـوط كـرده، بعـد از قـرار

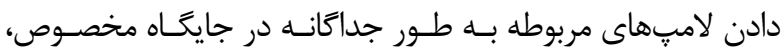
شروع به صفر كردن بلانكى دستخاه كرده و سيس شــروع بــه دادن استانداردهاى ساخته شده كرديم تا منحنى مناسب رسـم شـود و

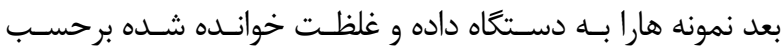
g/L در يرينتر نمايش داده شد كه نتـايج بايـد در رقـت سـاخته شده ضرب شود (بلانك، استانداردها و نمونهها هركـدام حــداقل r

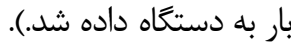
تمامى دادهها با استفاده از نرم افزار آمـارى يريسـم داده (Prism) و

جدول ا. جدول ميانگين و اختلاف معنى دار گروه نرمال و لوسمى

\begin{tabular}{|c|c|c|c|c|c|}
\hline P-value ${ }^{2}$ & P-value $^{1}$ & 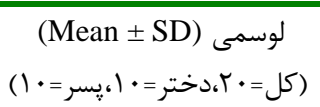 & 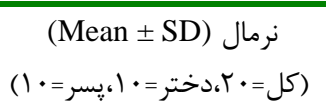 & تروه ها & متغيرها \\
\hline & $\mathrm{a} \cdot / \cdot \mathrm{V}$ & $V r / V \Delta \pm r \cdot / r q$ & $\Lambda \Delta / V \Delta \pm r \cdot / 9 r$ & كل - ا & $\mathrm{Zn}(\mu \mathrm{g} / \mathrm{dL})$ \\
\hline$d \cdot / 1 r$ & $\mathrm{~b} \cdot 199$ & $V F / F F \pm r \cdot / V G$ & $V N / \mathcal{S}_{ \pm} \mathrm{rM/V}$ & دختر & \\
\hline \multirow[t]{2}{*}{$e \cdot 119$} & $c \cdot / \cdot r$ & $\vee r / \backslash \Lambda \pm r I / \cdot \Lambda$ & $9 Y / 9 \pm 10 / V V$ & 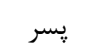 & \\
\hline & $a<\cdot / \cdots \cdot 1$ & $\mid r r / r \pm r V / \cdot r$ & $V N / T F \pm I T / F F$ & كل & $\mathrm{Cu}(\mu \mathrm{g} / \mathrm{dL})$ \\
\hline $\mathrm{d} \cdot / 4 \& 9 \mathrm{~V}$ & $\mathrm{~b} \cdot 1 \cdot 9 \mathrm{VV}$ & $11 \cdot / \Delta \pm F Y / T G$ & $\Lambda \cdot / r T \pm \mid r / \cdot r$ & دختر & \\
\hline \multirow[t]{2}{*}{$\mathrm{e} \cdot / \mathrm{r} \cdot \Lambda$} & $c<\cdot / \cdots \cdot 1$ & $|r| / 9 \pm r \cdot / \Lambda V$ & $V \varepsilon / 19 \pm|r /| F$ & 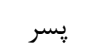 & \\
\hline & $a \cdot / r \omega$ & $V T / A r \pm 11 / \cdot V$ & $V \cdot|\Lambda| \pm \Lambda / \mu F$ & كل & Se $(\mu \mathrm{g} / \mathrm{L})$ \\
\hline $\mathrm{d} \cdot 19 \Lambda$ & $\mathrm{b} \cdot \mid q \mu$ & $\varepsilon N / T \pm V / V G$ & $V \cdot \pm N / T r$ & دختر & \\
\hline \multirow[t]{2}{*}{$\mathrm{e} \cdot 1 \cdot 1 q$} & $\mathrm{c} \cdot / \mathrm{IV}$ & $V A / F T \pm I T / G \Delta$ & $V I / G T \pm N / A r$ & يسر & \\
\hline & $a \cdot / \cdot r$ & $r / \cdot r \pm 1 / \Lambda 1$ & $F / F r \pm T / l$ & كل & $\operatorname{Mn}(\mu \mathrm{g} / \mathrm{L})$ \\
\hline$d \cdot / 4 \wedge$ & $\mathrm{b} \cdot / \mathrm{rr}$ & $r / T r \pm T / T Y F$ & $f / V q \pm 1 / q$ & دختر & \\
\hline $\mathrm{e} \cdot 19 \wedge$ & $c \cdot 119$ & $r / \wedge V \pm I / \Gamma \Delta$ & $Y / \cdot V \pm T / r r$ & يسر & \\
\hline
\end{tabular}

جدول r. مقايسه درون گَروهى و بين ₹روهى

\begin{tabular}{|c|c|c|}
\hline 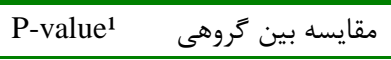 & P-value ${ }^{2}$ & مقايسه درون گروهى \\
\hline a كل نرمال با كل بيمار & & \\
\hline دختر نرمال با دختر بيمار b & & يسر نرمال با دختر نرمال d \\
\hline 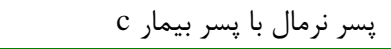 & & e يسر بيمار با دختر بيمار \\
\hline
\end{tabular}




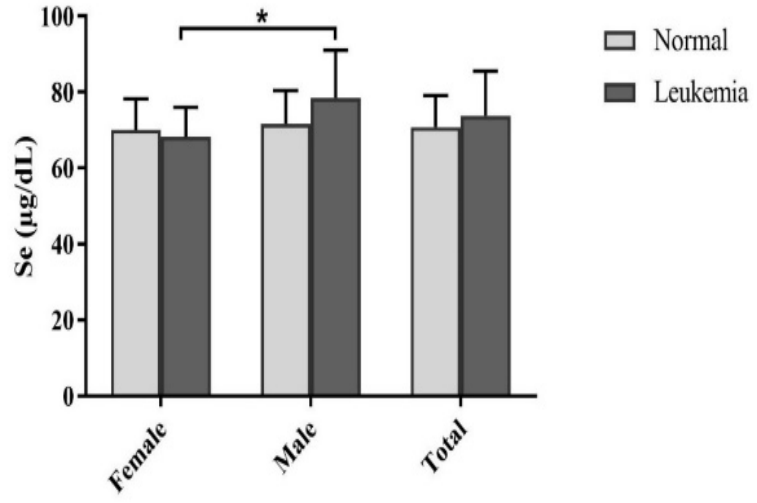

نمودار rا. مقايسه اختلاف معنىدار كل و جنسيتى در غلظت سلنيوم

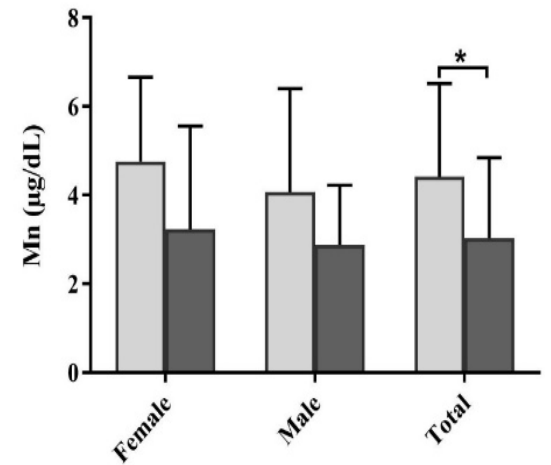

$\square$ Normal

$\square$ Leukemia

نمودار F. مقايسه اختلاف معنى دار كل و جنسيتى در غلظت منكَنز

\section{بحث}

لوسمى شايعترين سرطان در بين كودكان زير ها سـال اسـت

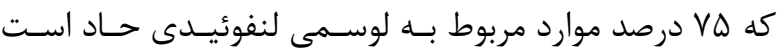

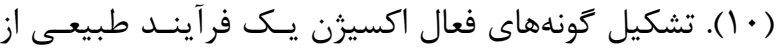
واكنشهاى ضرورى بيوشيميايى در بدن است (1). (1). كونهاى

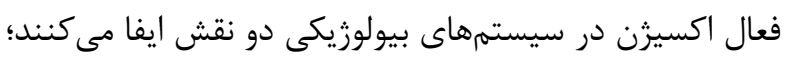
آنها مى توانند مضر و يا مفيد براى سيستمهاى زندي لنده باشند. استرس اكسيداتيو ممكن است مانع يا محرك آيويتوز و نكـروز شود كه اين وابسته به مقدار تحريك آنها است. تاثير سـودمند

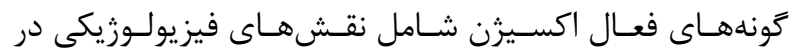

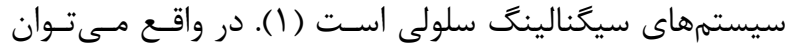

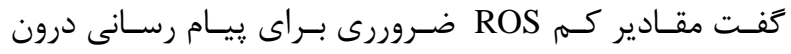

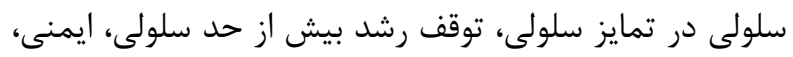

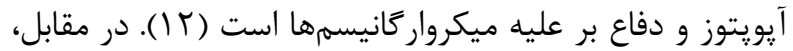

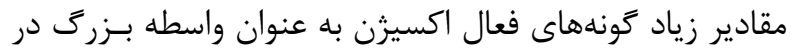

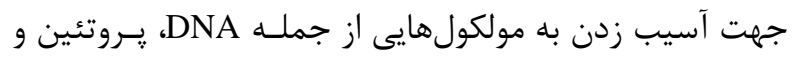

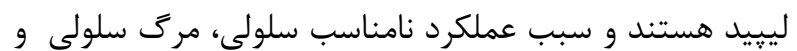

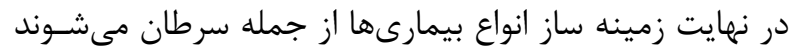

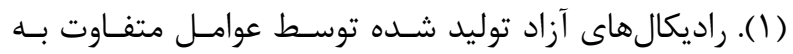

كنترل افزايش ناجيزى نشان داد كه معنى دار نبود. در مقايسـهـ

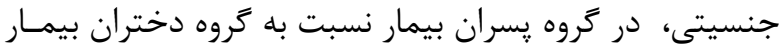

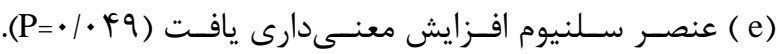

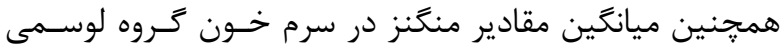

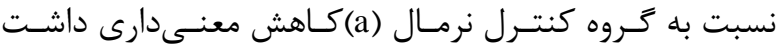
$(\mathrm{P}=\cdot / \cdot r)$

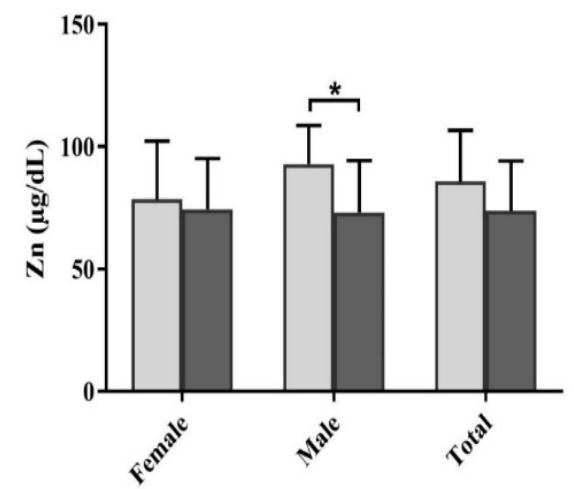

$\square$ Normal

$\square$ Leukemia نمودار ا. مقايسه اختلاف معنى دار كل و جنسيتى در غلظت روى

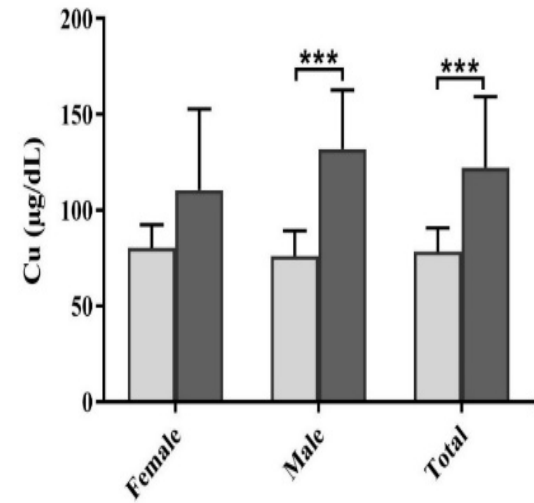

$\square$ Normal

$\square$ Leukemia

نمودار r. مقايسه اختلاف معنى دار كل و جنسيتى در غلظت مس

ترسيم آمارى نتايج دو كروه كنترل و لوسمى

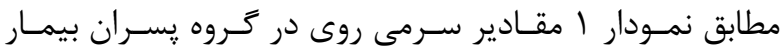
نسبت به پسران كنترل نرمال كاهش معنى دار (*) داشت.

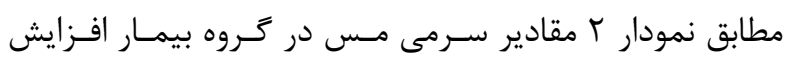

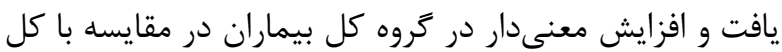

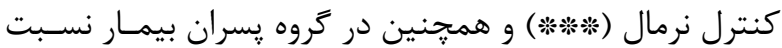
به بسران(*****) كنترل نرمال نشان داده شد.

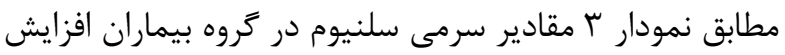

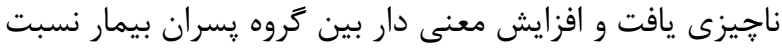
به دختران بيمار (**) نشان داده شد.

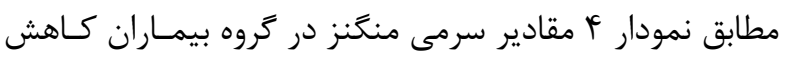

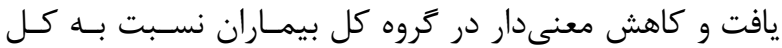
كنترل نرمال (**) وجود داشت. 
بررسى كردند كه با توجه به نتايج به دست آمـده، مقـادير مسس نسبت به گَروه كنتــرل افـزايش قابـل ملاحظـهاى را نشـان داد. مقادير سرمى مس در بدخيمىها افزايش مىيابد كه اين همـراه

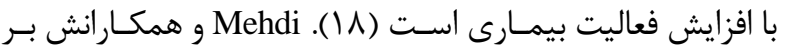
روى كودكان ALL تازه تشخيص داده شده، بررسى سطح سرمى مس با روش جــب اتمسى و سرولويلاسـمين اكسـيداز را انجـام دادند كه با توجه به نتايج به دست آمـده مقـادير بـالاى مـس در در

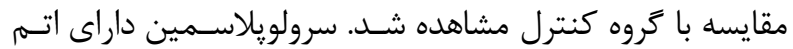

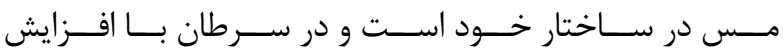
سرولويلاسمين مقادير مس نيز افزايش مىيابد (Y). هـم جنــين

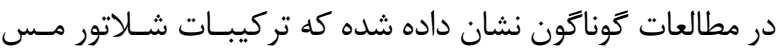
مىتوانند به عنوان مهار كنندهُ تومور عمـل كننــد (9 (1). بـيش از

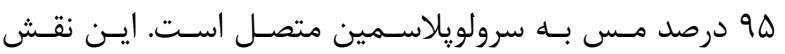

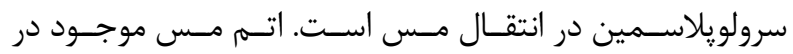
سرولويلاسمين ضرورى براى عملكرد در بيوسنتز سـيتوكروم

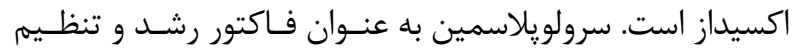
كننده عملكرد يروتئين عمل مى كند (r). منحَنز عنصر كمياب و و

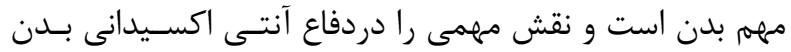
ايفا مى كند. اين عنصر بخشى از آنـزيم سويراكسيدديسـموتاز

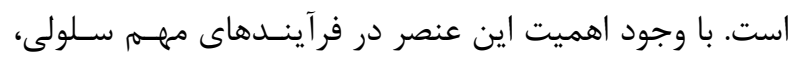

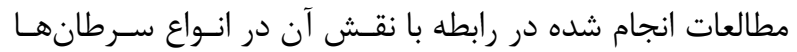

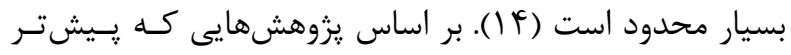

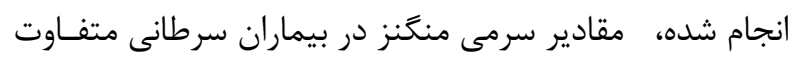

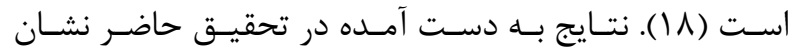
مى دهد كه مقادير منگَنز در كودكان مبتلا به لوسـمى نسـبت

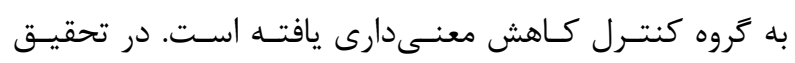

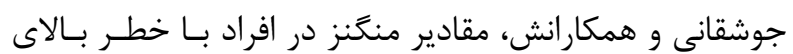

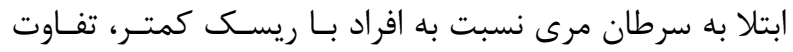

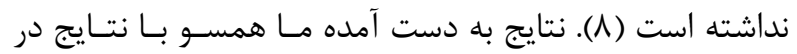

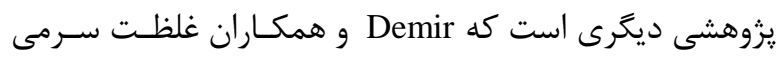

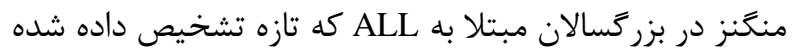
بودند را اندازه گيرى كردند. آنها مشاهده كردند مقادير منَخنز نسبت به گروه كنترل به طورقابل ملاحظهاى كمتر است (1) (1).

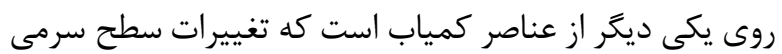
آن در فرآيند اكسيداسيون و احيا و ايجـاد يديـده كارسـينوزنز موثر است. روى يكى از آنتى اكسيدانهاى مواد غذايى است كه فعاليت آنزيمهاى موجود در سيستم آنتى اكسيدانى بدن مثـل رئل

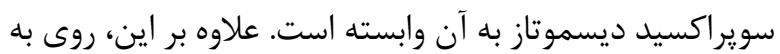

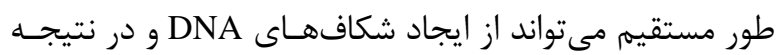

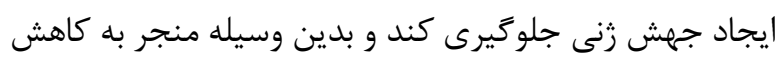

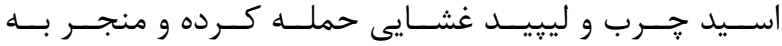
يراكسيداسـيون جربسى و در نهايـت مـرگت سـلولى مسىشـوند. يراكسيداسيونهاى ليبيدى نقش كليدى در سرطانزايى دارند

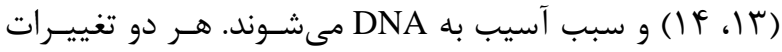

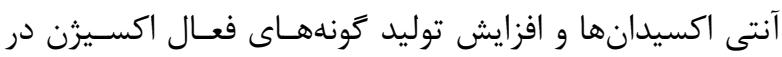
سرطان زايى كزارش شدهاند (1). كاهش آنتى اكسيدانها خود

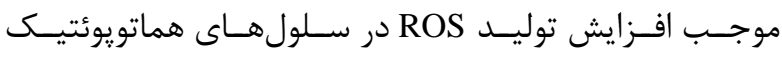
(خونساز) مىشوند و اين افزايش ROS سبب متاستاز تومورها

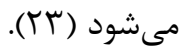
در اين تحقيق اندازهيرى سطح سرمى عناصر آنتى اكسيدان در

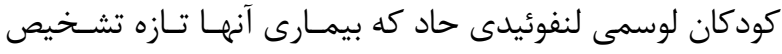

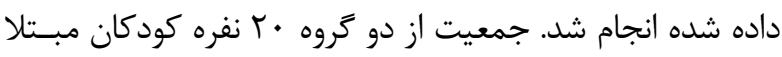

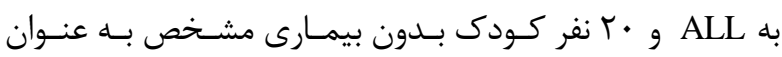
كنترل انجام شد. نتايج حاصل از تحقيق حاضر نشان مىدهد كه سطح سرمى عناصر كمياب مس و منغَنز در كودكـان مبـتلا بــهـ لوسمى در مقايسه با كودكان غيرمبتلا اختلاف معنسى دارى دارد.

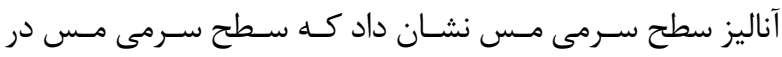
كودكان مبتلا به لوسمى در مقايسه با كودكان كنتــرل، افـزايش قابل توجه و معنى دارى دارد. Lagos و همكارانش بررسى سطح سرمى مس مس را برروى بيمـاران

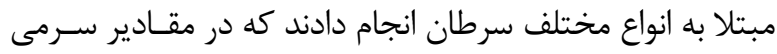

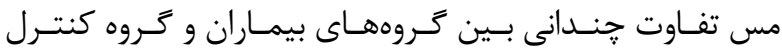

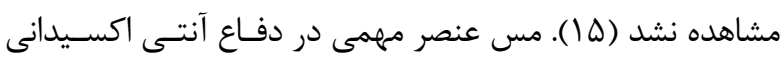

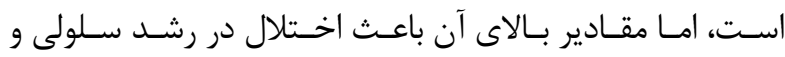
سرطان از طريق آسيب زدن راديكال هاى آزاد به DNA مىشود؛

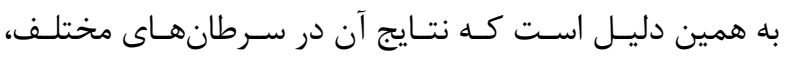

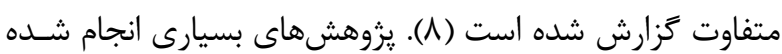

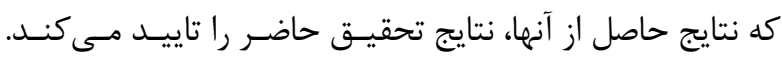
Sgarbieri

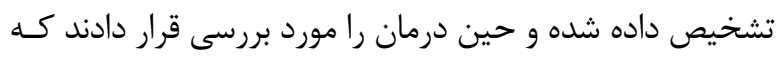

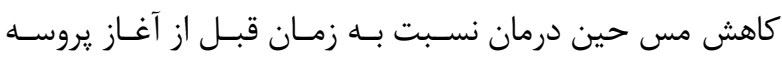

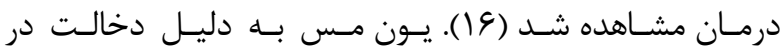
فعاليتهاى اكسيد و احيا نقش اساسى در توليـد متابوليـتهــاى

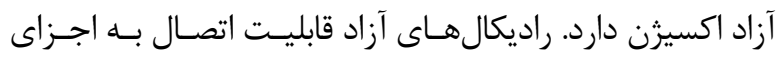
طبيعى سلول را داشـته و منجــر بـه :راكسيداسـيون جربـىهــا،

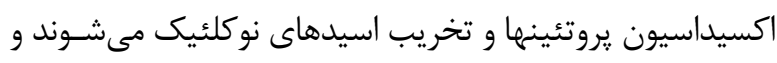

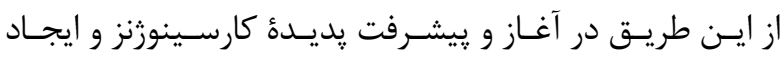

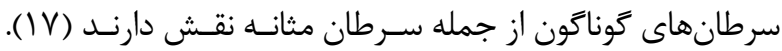

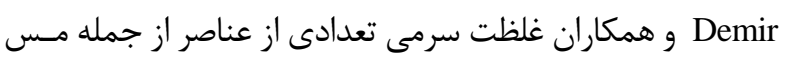

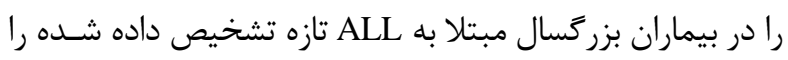


كودكان مبتلا به لوسمى نسبت به گروه كنترل تغيير جنــانى

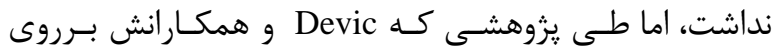
كودكان مبتلا به ALL انجام دادند و مقادير سـلنيوم سـرمى را قبل از شروع يروسه شيمى درمانى با روش جذب اتمسى مــورد بررسى قرار دادند، نسـبت بـه تَروه كنتــرل كـاهش سـلنيوم مشاهده شد ( (Y). در تحقيق Habbani و همكـارانش مقــادير سرمى سلنيوم درگروه لوسمى لنفوئيدى حـاد يـيش از شـروع

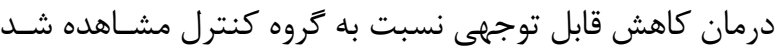
(9 (). در تحقيق Asadi اندازه گيرى سطح سرمى سـلنيوم در

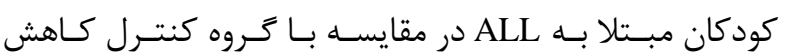

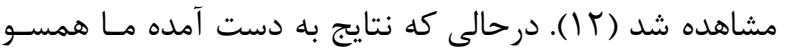
با يزوهشى است كه Pazirandeh و همكارانش برروى كودكـان

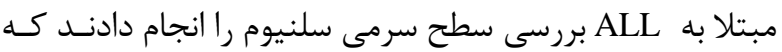

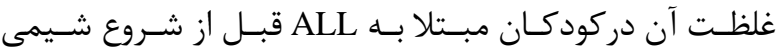
درمانى تغيير قابل ملاحظهاى با كودكان كنترل نداشت، اما يس

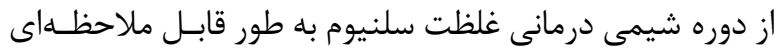
كاهش نشان داد (TY). با توجه با نتايج به دست آمده از اين يروهش، افزايش معنىدار عنصر مس در كودكان مبتلا به لوسمى قبل از درمـان نسـبت

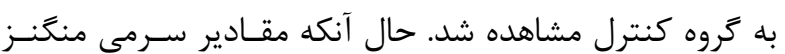
كاهش معنى دارى در كودكان لوسمى داشت. به علاوه، تفـاوت معنى دارى در مقادير سرمى روى و سـلنيوم در ايـن دو گَروه مشاهده نشد. به نظر مىرسد كه تغييـرات سـطح سـرمى ايسن فئن آنتى اكسيدانها مى توانند نقش بيولوزيكى مهرمى در شروع يـا ״يشروى سرطان خون داشته باشند كه در صـورت اثبـات ايسن

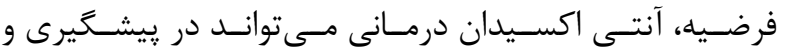

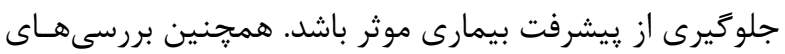
بيشترى جهت روشن كردن نقش اين فاكتورها در بيمـاريزايى لوسمى حاد نياز است.

\section{تشكر و قدردانى}

مراتب سياس خود را از سر كار خانم افشار كارشناس آزمايشگاه بيوشيمى دانشكده علوم يزشكى دانشخاه تربيـت مــدرس ابـراز كرده و كمال تشكر و قدردانى را از ايشان دارم.
خطر ابتلا به سرطان شود. از اين رو كاهش سطح سـرمى روى مى تواند از طريق كاهش اثرات حفاظتى و كـاهش اثـرات آنتى اكسيدانى آن منجر به ايجاد سرطانهاى گونـاگون شـود (IV) مطالعات نشان مى دهند كـهـ سـطوح سـرمى روى در بيمـاران مبتلا به لوسمى در مقايسه با افراد سالم معمـولا دجــار تغييـر مىشود. در اين تحقيق سطح سرمى روى در كودكان مبتلا بـــ

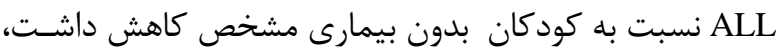
اما اين اختلاف معنى و همكارانش بررسى سطح سـرمى روى را بـرروى بزرگسـالان

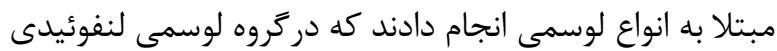
حاد يیش از شروع درمان افزايش قابل توجهى در مقـادير روى

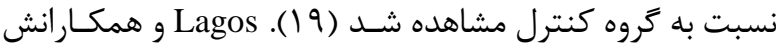
بررسى سطح سرمى روى در بيماران مختلف سـرطانى را انجـام دادند كه مقدار سرمى يايين روى نسبت به كروه كنترل نشـان داده شد كه اين به دليل نقش حفــاظتى روى در مقابـل بــروز

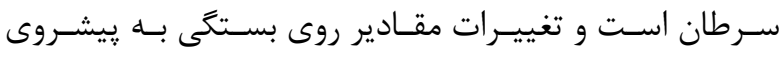

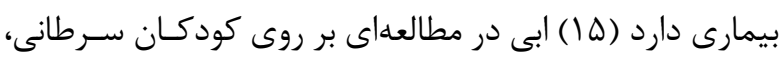
مقادير سرمى روى را مورد بررسى قرار داد و به اين نتيجه رسيد كه سلولهاى لوسمى در مقايسه با لنفوسيتهاى سالم حـاوى روى كمترى هستند. طى درمان با مكمل روى در اين بيمـاران

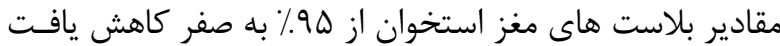
و بيمارى دوباره عود نكرد (· ·). در تحقيق Sgarbieri مقـادير سرمى روى در كودكان ALL تازه تشخيص داده شده و حـين

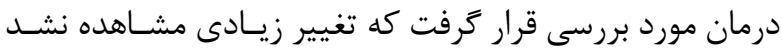

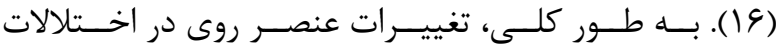
لنفويروليفراتو ديده مىشود. در تحقيـق Demir، مقـادير روى

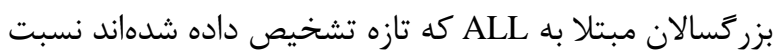
به گروه كنترل به طورقابل ملاحظهاى كمتر بود (1) (1). سلنيوم يك عنصر كمياب و ريزمغذى ضرورى بـراى سـلامتى

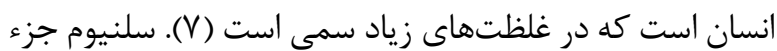

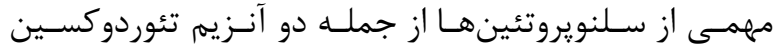

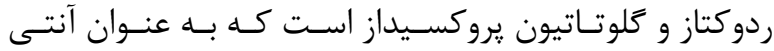

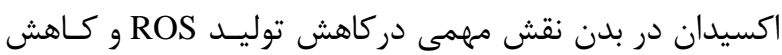

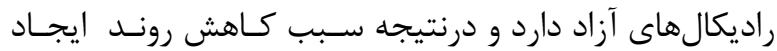
سرطان مىشود ( (Y). در اين تحقيق مقادير سرمى سلنيوم در

\section{REFERENCES}

1. Battisti V, Maders LD, Bagatini MD, Santosa KF, Rosélia M, Spanevello B, et al. Measurement of oxidative stress and antioxidant status in Acute lymphoblastic leukemia patients. Clin Biochem 2008;41:511-8.

2. Mehdi WA, Yusof F, Mehde AA, Zainulabdeen JA, Raus RA, Abdulbari AS. Effects of Acute Lymphoblastic Leukemia on Ceruloplasmin Oxidase, Copper and Several Markers of Oxidative Damage,in Children. Asian Pac J Cancer Prev 2015;16:5205-10. 
3. Hadi N, Moezi M, Etehadi H. Investigation of risk factors of acute leukemia in children below 15 years in Shiraz. Daneshvar Journal 2007;67. [In Persian]

4. Baradaran B, Tartibian B, Baghaiee B, Monfaredan A. Correlation between superoxide dismutase 1 gene expression with lactate dehydrogenase enzyme and free radicals in female athletes: effects of incremental intensity exercises. Tehran Univ Med J 2012;4:212-9. [In Persian]

5. Diaz de Barboza G, Guizzardi S, Moine L, Tolosa de Talamoni N. Oxidative stress, antioxidants and intestinal calcium absorption. World J Gastroenterol 2017;23:2841-53.

6. Mazdak H, Mirkheshti N, Movahedian A, Yazdekhasti F, Behzad E, Shafieian M, et al. The study of the serum manganese concentration in the bladder cancer patients in comparison with healthy subjects. J Isfahan Med Sch 2008;26:267-72.

7. Salmani Nodoushan MH, Abedi M, Vakilli M. Selenium and Human Health. Shahid Sadoughi Univ Med Sci 2013;21:101-12. [In Persian]

8. Joshaghani H, Mirkarimi H, Besharat S, Roshandel Gh, SanaeiO, Nejabat M. Comparison of the Serum Levels of Trace Elements in Areas with High or Low Rate of Esophageal Cancer. Middle East J Dig Dis 2017;9:81-5.

9. Zarghami N, Asadi J, Mahbob S, Mohammadzadeh G, Mohajeri A. Serum Levels of Se, Zn, Cu and Cu / Zn Ratio in Iranian Breast Cancer Patients. J Pharm Sci 2008;1:27-32. [In Persian]

10. El-Sabagh ME, Ramadan KS, El-slam IMA, Ibrahim AM. Antioxidants Status in Acute Lymphoblastic Leukemia Patients. American Journal of Medicine and Medical Sciences 2011;1:1-6.

11. Skrzydlewska E, Sulkowski S, Koda M, Zalewski B, Kanczuga Koda L, Sulkowska M. Lipid peroxidation and antioxidant status in colorectal cancer. World J Gastroenterol 2005;11:403-6.

12. Assi S, Ryaidh Sh. Al Husain: Study of Protective effect of Glutathione Peroxidase (GSH-Px), Vitamin E and Selenium on Iraqi children with Leukemia. J Biotechnol Res 2014;8:4.

13. Rezaeyan A, Haddadi GH, Hosseinzadeh M. Evaluating Superoxide Dismutase (SOD), Glutathione (GSH), Malondialdehyde (MDA) and the Histological Changes of the Lung Tissue after $\gamma$-Irradiation in Rats. J Fasa Univ Med Sci 2016;6:235-45. [In Persian]

14. Feng Zh, Wenwei Hu, Moon-shong Tang. Trans-4-hydroxy-2-nonenal inhibits nucleotide excision repair in human cells: A possible mechanism for lipid peroxidation-induced carcinogenesis. Proc Natl Acad Sci U S A 2004;101:8598602.

15. Martín-Lagos F, Navarro-AlarcónC M, Terrés-MartosH C, López-G de la Serrana H, López-Martínez MC. Serum copper and zinc concentrations in serum from patients with cancer and cardiovascular disease. Sci Total Environ 1997;204:27-35.

16. Sgarbieri UR, Fisberg M, Tone LG, Latorre Mdo R. Nutritional assessment and serum zinc and copper concentration among children with acute lymphocytic leukemia. Sao Paulo Med J 2006;124:316-20.

17. Mazdak H, Mirkheshti N, Movahedian A, Yazdekhasti F, Behzad E, Shafieian M. The study of the serum iron,copper and zinc concentration in the bladder cancer patients in comparison with healthy subjects. J Isfahan Med Sch 2010;1:56-60. [In Persian]

18. DemirC, Demir H, Esen R, Sehitogullari A, Atmaca Alay M. Altered Serum Levels of Elements in Acute Leukemia Cases in Turkey. Asian Pac J Cancer Prev 2012;12:3471-4.

19. Elradi MMM. Investigation of Selected Trace Elements in Sudanese Patients with Leukemia using NAA. Sudan Academy of Sciences (SAS) Atomic Energy Council. 2010.

20. Eby GA. Treatment of acute lymphocytic leukemia using zinc adjuvant witchemotherapy and radiation-a case history and hypothesis. Med Hypotheses 2005;64:1124-6.

21. Mikac-Dević M, Ferenec D, Tiefenbach A. J Trace Elem Electrolytes Health Dis 1990;4:7-10.

22. Pazirandeh A, AssadiNejad M, Vossogh P. Determination of Selenium in Blood Serum of Children with Acute Leukemia and Effect of Chemotherapy on Serum Selenium Level. J Trace Elem Med Biol 1999;13:242-6.

23. Rasool M, Farooq S, Malik A, Shaukat A, Manan A, Asif M, et al. Assessment of circulating biochemical markers and antioxidative status in acute lymphoblastic leukemia (ALL) and acute myeloid leukemia(AML) patients. Saudi J Biol Sci 2015;22:106-11. 